\title{
OTIMIZAÇÃO DO TRATAMENTO DE EFLUENTES DE FRIORICO COM ADIÇÃO DE ADITIVO BIOLOGICO
}

\section{Beatriz Lene Falcão*, Cassiana Maria Reganhan Coneglian. Faculdade de Tecnologia/campus I de Limeira.}

\section{Resumo}

Com o grande crescimento e desenvolvimento da pecuária em todo o território brasileiro, um dos desafios encontrados na produção de carne é a quantidade elevada de água residuária (efluente) gerada no processo de abate dos animais. O efluente gerado é formado principalmente por matéria orgânica, proveniente de fezes, urina e sangue dos animais abatidos. O tratamento do efluente deve ser adequado visando atender as normas vigentes para que o descarte no corpo hídrico, uma vez que o descarte de forma indevida pode causar danos sérios à vida aquática. Desta forma, este projeto teve como objetivo otimizar o tratamento de efluentes de frigorífico utilizando o aditivo biológico, denominado Componente "E", produzido por processo de compostagem líquida a partir de esterco bovino, visando otimizar o processo de nitrificação.

Palavras-chave: amônia, biodegradação, aditivo biológico.

\section{Introdução}

Os efluentes gerados nas unidades de abatedouros de bovinos e suínos apresentam elevadas concentrações de matéria orgânica carbonácea e nitrogenada. Os parâmetros Demanda Bioquímica de Oxigênio (DBO) e Demanda Química de Oxigênio (DQO), são amplamente utilizados para quantificar carga poluidora orgânica dos efluentes, além dos nutrientes nitrogênio e fósforo, principais componentes para avaliar a eutrofização de corpos d'água.. Sendo assim neste trabalho monitorouse o tratamento biológico de efluentes gerado em abatedouro de bovinos e suínos, com histórico do não atendimento ao padrão de lançamento de efluentes no parâmetro nitrogênio amoniacal. Objetivou-se ainda otimizar o tratamento biológico mediante a adição de aditivo biológico, denominado Componente " $E$ ", com vistas ao atendimento das legislações vigentes Conama 357/2005 e Conama 430/2011, além da garantia da proteção ambiental.

\section{Resultados e Discussão}

Realizou-se 6 campanhas de coleta em 3 pontos na planta de tratamento biológico dos efluentes gerados em frigorifico na região de Piracicaba, SP, sendo: entrada da lagoa 3 (ponto 1), saída da lagoa 3 (ponto 2) e efluente final (ponto 3). Para o monitoramento do tratamento do efluente avaliou-se os seguintes parâmetros: Oxigênio Dissolvido (OD), nitrogênio amoniacal $\left(\mathrm{NH}_{3}\right)$, Demanda Bioquímica de Oxigênio (DBO), Demanda Química de Oxigênio (DQO), $\mathrm{pH}$, alcalinidade total, turbidez, cor e condutividade. Para otimizar o tratamento adicionou-se o componente "E" na terceira lagoa, no qual foram instalados dez aeradores superficiais. O componente "E" (CE) foi aplicado na concentração de 05\% (v/v), na terceira lagoa.
Tabela 1: Resultados da concentração de nitrogênio amoniacal ( $\left.\mathrm{mg} \mathrm{NH}_{3} / \mathrm{L}\right)$ nos três pontos de coleta de efluente

\begin{tabular}{cccccccc}
\hline & \multicolumn{6}{c}{$\begin{array}{c}\text { Campanhas de Coleta } \\
\mathrm{NH}_{3}(\mathrm{mg} / \mathrm{l})\end{array}$} \\
\hline Pontos & $\mathbf{1}$ & $\mathbf{2}$ & $\mathbf{3}$ & $\mathbf{4}$ & $\mathbf{5}$ & $\mathbf{6}$ \\
& & & & & & \\
$\mathbf{1}$ & $*$ & 147 & 108,08 & 114,5 & 123,2 & 131,04 \\
$\mathbf{2}$ & $*$ & 96,9 & 99,12 & 107,6 & 114,8 & 123,76 \\
& & & & & & \\
$\mathbf{3}$ & $*$ & 101,6 & 90,72 & 98,4 & 113,7 & 114,8
\end{tabular}

\section{Conclusões}

Os resultados indicam a ineficiência de remoção da carga orgânica nitrogenada, avaliada pela análise de nitrogênio amoniacal ( $\mathrm{mg} \mathrm{NH}_{3} / \mathrm{L}$ ), fato este diretamente relacionado com a baixa oxigenação do sistema, comprovada pela quantificação média de OD de 0,5 e 0,6 mg/L na entrada e na saída da lagoa, respectivamente. Para que ocorra a nitrificação, processo bioquímico microbiano responsável pela remoção de nitrogênio amoniacal faz-se necessário manter no sistema aproximadamente $2,0 \mathrm{mg} \mathrm{O}_{2} / \mathrm{L}$.

BRASIL. Conselho Nacional de Meio Ambiente. Resolução nº 430, de 13 de maio de 2011. Dispõe sobre as condições de lançamento de efluentes, complementa e altera a Resolução $\mathrm{n}^{\circ} 357$, de 17 de março de 2005, do Conselho Nacional do Meio Ambiente. Disponível em: <http://www.mma.gov.br/conama $>$. Acesso em 10 de abril de 2018.

BRASIL. Conselho Nacional de Meio Ambiente. Resolução n ${ }^{\circ}$ 357, de 17 de março de 2005. Dispõe sobre a classificação dos corpos de água e diretrizes ambientais para o seu enquadramento, bem como estabelece as condições e padrões de lançamento de efluentes, e dá outras providências. Disponível em: <http://www.mma.gov.br/conama>. Acesso em 10 de abril de 2018. 